\title{
Л.В. Березіна
}

\section{СУЧАСНІ МОЖЛИВОСТІ ЛАЗЕРОТЕРАПІЇ НЕЙРОІНФЕКЦІЙ}

\author{
Інститут епідеміології та інорекційних хвороб ім. Л.В. Громашевського НАМН України, м. Київ
}

Огляд літератури присвячений сучасним уявленням про дію лазерного опромінення на організм. Показано сучасні можливості використання лазеротерапії при нейроінорекціях.

Ключові слова: нейроінфекції, лазерне опромінення, неврологія, лазеротерапія.

Нейроінфекції залишаються серйозною проблемою охорони здоров'я і належать до поліетіологічних захворювань, що спричинюються різними збудниками, серед яких провідне значення надається вірусам. Віруси знижують фрункціональну активність імунної системи, що призводить до тяжкого клінічного перебігу захворювань та виникнення різних ускладнень з боку серцево-судинної системи, легень, нервової системи, i, як правило, є пусковим механізмом автоімунних захворювань. Незважаючи на успіхи в лікуванні, летальність при нейроінфекціях залишається досить високою - 10-28 \%. Після перенесеного захворювання у 60-80 \% хворих зберігаються залишкові неврологічні та психотичні ускладнення: астеновегетативний синдром, астеноневротичний, синдром хронічної втомлюваності, гідроцефралічний, парези, паралічі, що призводить до суттєвого зниження працездатності та розвитку інвалідності [1].

Різноманітність клінічних фрорм нейроіноекцій, їх патогенетичних механізмів обумовлена як особливостями збудників, так і фенотипичними особливостями організму людини. Все це впливає на своєчасність топічної діагностики, адекватність оцінки виразності патологічного процесу, ускладнює вибір тактики лікування, призводить до тяжких наслідків. Слід визначити, що органолокалістичність нейроінфрекцій: енцефаліт, енцефраломієліт, арахноенцефаліт - недостатньо вмістовні для визначення обсягу та характеру патологічного процесу в цілому, оскільки в патологічний процес в більшому чи меншому ступені залучаються органи й системи всього організму [2].

Одна з проблем сучасної медицини - лавиноподібне збільшення споживання лікарських засобів специфічної дії. Тільки за останні десять років обсяг світового ринку фармацевтичних товарів збільшився майже вдвічі і про- довжує рости. Ні для кого не секрет, що при тривалому прийомі багатьох лікарських препаратів виникають алергічні реакції, зростає толерантність і розвивається рефрактерність до медикаментів. Не можна заперечувати значимість специфрічної терапії, але негативна дія, що нею спричинюється і приводить до зниження власних захисних сил організму, не завжди компенсується лікувальним ефектом. Все це обумовлює зростаючий інтерес лікарів до неспециорічних методів лікування, які забезпечують необхідний результат опосередковано, через підвищення резистентності організму [3].

Досі актуальними залишаються слова відомого вченого Ганса Сельє, який так описував причину, що спонукала його до пошуку нових способів лікування: «я не міг зрозуміти, чому лікарі з незапам'ятних часів концентрували свої зусилля на розпізнавання окремих нозологічних фрорм і пошуках специфічних ліків, придатних для лікування лише цих окремих хвороб, не приділяючи жодної уваги «синдрому становлення хвороби». Адже якщо важливо знайти засоби, що допомагають при тому чи іншому захворюванні, то набагато більше необхідно вивчити механізм виникнення хвороби і знайти засоби лікування того «загального синдрому хвороби», який, мабуть, більш суттєвий, ніж все специфічне в ній!» [4].

У цьому аспекті, на нашу думку, перспективним методом терапії, доступним для великої кількості хворих, може стати використання в лікуванні фротонів світла [5], які мають багатогранну дію [6] як на віруси [7], так і на організм людини в цілому [8].

Низькоінтенсивне лазерне опромінення (НІЛО) все ширше застосовується в самих різних ділянках медицини завдяки численним експериментально-клінічним даним, що свідчить про високу терапевтичну ефективність когерентного електромагнітного опромінення оптичного діапазону. Про відсутність ускладнень і побічних ефектів при дії НІЛО відомо ще з початку 70-х років минулого століття. Цілющі властивості сонячного світла були відомі людству у всі часи. Численні згадки про використання променів Сонця в лікувальних цілях можна знайти у Геродота, Гіппократа, Галена, Авіценни та ін. [9].

Лазери без перебільшення справили переворот в багатьох галузях науки і техніки, в тому числі й в медицині. 
Що стосується лазерної терапії, то в історичному аспекті можна зробити однозначний висновок про виникнення у наш час якісно нового етапу розвитку світлотерапії [10]. Лазерна терапія актуальна в даний час як ніколи, оскільки деякі з відомих методів лікування якщо не вичерпали себе, то стали різко обмеженими у застосуванні з об'єктивних причин.

Біологічна дія НІЛО розглядається, як правило, у вигляді послідовного ланцюжка процесів, які відбуваються у часі, починаючи з живої клітини і закінчуючи «терапевтичним» ефректом, коли мається на увазі вже конкретний практичний результат клінічного застосування. Взаємодія лазерного світла з біологічною системою відбувається в два основних етапи: первинний механізм, що полягає в безпосередньому поглинанні світлової енергії, і вторинні механізми, коли в значній мірі вже після закінчення опромінення розвивається каскад вторинних відповідних реакцій, які є, власне, основним «лікувальним фрактором». Лазерне опромінення дозволяє усвідомлено і контрольовано викликати ефективний відгук потрібної сили і спрямованості практично всіх систем, що підтримують гомеостаз, що в результаті зумовлює найкращий лікувальний ефект [9].

Дія низькоінтенсивного лазерного опромінення на біологічні об'єкти неспецифічна, як наслідок цього максимально універсальна. Само лазерне світло не $є$ терапевтичним агентом і нічого не лікує, а лише ініціює відповідну реакцію організму. Отже, лазерне світло у терапії - це зовнішній регулятор клітинної біохімічної активності і фрізіологічних функцій організму в цілому. Принципово важливо розуміти взаємодію НІЛО з біологічними об'єктами у вигляді багатоступінчастого процесу, що розвивається після первинного акту поглинання енергії фротона. Зазвичай виділяють два незалежних етапи зі своїми механізмами: первинний процес і вторинні реакції. Оскільки при вивченні терапевтичних ефектів лазерного впливу також розглядаються клінічні аспекти, в медичній літературі найчастіше умовно додають і їх:

1) первинні процеси (зміна стану електронних рівнів молекул живої речовини, стереохімічна перебудова молекул, локальні термодинамічні зрушення, виникнення підвищеної концентрації $\mathrm{Ca}^{2+}$ в цитозолі);

2) вторинні есректи (поширення хвиль підвищеної концентрації $\mathrm{Ca}^{2+}$ у клітині і між клітин, стимуляція (або пригнічення) $\mathrm{Ca}^{2+}$-залежних біопроцесів на клітинному рівні, зміна фрункціонального стану як окремих систем біологічної клітини, так і організму в цілому);

3) ефректи післядії (утворення продуктів тканинного обміну, відгук систем імунного, нейрогуморального, ендокринного регулювання тощо).

Все це і визначає широкий спектр відповідних реакцій організму на лазерний вплив, починаючи від первинного акту поглинання енергії фотона і закінчуючи реакцією різних регулюючих систем організму [9]. Крім того, на тлі лазеротерапії потреба хворих у лікарських препаратах різко знижується при одночасному посиленні та пролонгації їх фрармакологічної дії, також зменшується вірогідність проявів можливих побічних ефректів. За наявності алергічної реакції у пацієнтів на ліки лазерна терапія взагалі безальтернативна.

В успішному рішенні питань, пов'язаних з ефективністю лазеротерапії, велика роль відводиться раціонально підібраним параметрам опромінення. Одна із самих підступних якостей лазеротерапії - різка залежність ефекту від дози дії та фрункціонального стану біологічного об'єкта. Позитивна стимулююча дія проявляється, як правило, у вузькому інтервалі доз, а потім зникає або навіть змінюється пригнічувальною дією.

У клінічній практиці використовуються різні способи доставки фотонів світла: внутрішньовенне лазерне опромінення крові (ВЛОК); підведення до патологічного вогнища за допомогою ендоскопічної техніки; черезшкірна дія на больову точку або проекцію органа; дія на рефрлекторні точки акупунктури і зони Захар"їна-Геда; надвенна дія на кров [11]. Кожен із цих способів має свої недоліки та переваги. Найоптимальнішим є метод, при якому наявна безпосередня взаємодія лазерного опромінення з компонентами крові: клітинами, ліпопротеїнами та білками.

Перспективи використання лазерної терапії нервових хвороб цікаві також тим, що вивчаючи взаємодію лазерного опромінення 3 нервовою тканиною, ми починаємо розуміти і механізми нейрогуморальної регуляції в цілому, механізми опосередкованої (через нервову систему) дії НІЛО на інші фрізіологічні субодиниці організму. Розглянемо деякі дані наукових досліджень по темі, щоб зрозуміти - ми знаходимося тільки на порозі усвідомлення тих можливостей, які нам надасть виявлення закономірностей взаємодії НІЛО і нервової системи. Лазерне опромінення, залежно від дози і довжини хвилі, може викликати стимуляцію, гальмування або необоротне блокування імпульсації нейрона річкового рака [12], а багаточастотна модуляція опромінення виявляється ще більш ефективним керуючим фрактором у даній моделі. Аналіз імпульсної активності нейронів довгастого мозку щурів після впливу гелий-неонового лазера виявив, що біоелектрична активність нейронів проявляється трьома фрормами: реакція активації (у 50 \% клітин), реакція гальмування (у $37 \%$ ), нейтральна реакція (при якій частотні характеристики біоелектричної активності не змінюються) спостерігається у $13 \%$ клітин. Характер реакції кожного конкретного нейрона залежить насамперед від місця, займаного даною клітиною в нервовому центрі, та її ролі у межцентральній 
інтеграції [9]. Виявлені зміни є наслідком неспецифрічних змін метаболічних процесів у нервовій тканині.

Згідно з проведеними дослідженнями, при впливі на аурикулярні точки людини світлом гелий-неонового лазера спостерігаються зрушення в біоелектричній активності різних ділянок головного мозку (за даними ЕЕГ), при цьому характер змін істотно залежить від частоти модуляції опромінення і наявності тієї чи іншої патології нервової системи [13]. Це доводить можливість включення ЦНС і ВНС у процеси стимульованих лазерним опроміненням змін гомеостазу на рівні організму в цілому, що також було обґрунтовано [14].

Встановлено, що при впливі імпульсного інфрачервоного НІЛО на тім'яну ділянку голови щурів з частотою 10 Гц (близькою до альфра-ритму головного мозку) створюється оптимальне пластичне забезпечення для високої функціональної активності як нейронів кори головного мозку, так і міоцитів скелетних м'язів, що знаходяться під регуляційним впливом рухового центру [15].

Показано виражену антигіпоксичну дію НІЛО на нейрони головного мозку щурів і мишей, залежну від дози [16]. При впливі опроміненням лазера на периферичний нерв спостерігаються два основні ефекти: знеболювальна дія як наслідок протизапального ефекту НІлО і стимуляція посттравматичної регенерації нервових волокон.

Більшість дослідників вважає, що стимуляція посттравматичної регенерації відбувається за рахунок поліпшення мікроциркуляції та інтенсивності місцевого кровотоку, стимуляції проліферації і диференціювання різних клітинних типів - від макрофагів до шванівських і периневральних клітин, зміни морфофункціональних властивостей осьового циліндра і аксонного транспорту в ньому. В ході уоллерівської дегенерації макрофаги усувають залишки дистальної ділянки нервового волокна, включаючи фрагменти мієліну, який містить чинники, що гальмують регенерацію. Крім того, макрофраги впливають на шванівські клітини, підтримуючи їх у стані, найбільш адекватному активному росту нервового волокна [17].

Незважаючи на численні труднощі в теоретичній частині, лазерна терапія в практичній неврології знаходить все ширше застосування.

При вегето-судинній дистонії використовуються судинорозширювальний та спазмолітичний ефекти ВЛОК, відбувається нормалізація вегетативно-судинних розладів [18].

Ефективність ВЛОК при вібраційній хворобі, в основі патогенезу якої лежить складний механізм нервових і рефлекторних порушень, що призводять до стійких змін периферичної нервової системи, судинного тонусу, мікроциркуляторної системи, гемостазу та електролітного промена, підтверджується позитивною динамікою клінічних проявів захворювання, стану периферичного кровообігу, біостимулюючою дією на нервово-м'язову систему, поліпшенням реологічних властивостей крові, гіпокоагуляційним ефектом, оптимізацією концентрації $\mathrm{Ca}^{2+}$ плазми. Основні кількісні показники реологічних властивостей крові (в'язкість цільної крові, в'язкість плазми, агрегація еритроцитів) можуть служити інорормативним критерієм для ранньої діагностики вібраційної патології, а також оцінки ступеня виразності захворювання та ефрективності проведеного лікування [9].

Фахівці у своїй практиці досить часто зустрічаються 3 гіпоталамічним синдромом, який представляє собою багатофракторний комплекс вегето-судинних, трофрічних і нервово-психічних розладів. Вони, як правило, не перебігають самостійно, а супроводжують або служать своєрідним ускладненням ряду соматичних, метаболічних і ендокринних захворювань і патологічних станів (конституційно-екзогенна та інші фрорми ожиріння і синдроми, в яких воно є невід'ємним патогенетичним компонентом; цукровий діабет, порушення функції залоз внутрішньої секреції, включаючи пухлини тощо). Синдром дуже різноманітний за характером і ступенем виразності клініко-синдромологічних проявів, що обумовлено провідною роллю гіпоталамічної ділянки головного мозку в регуляції вегетативних, троорічних і сполучених психічних функцій. ВЛОК впливає на центральну і регіональну гемодинаміку, а також седативну та спазмолітичну дію, відбувається скорочення прийому лікарських препаратів і термінів лікування [19].

Велика кількість причин і клінічних фрорм цефралгічного синдрому ускладнює його швидку етіологічну ідентисрікацію. Виділяють кілька десятків різновидів головного болю, для більшості з яких не виявляється однозначної причини, а лікування, як правило, носить тривалий характер, не завжди приносить успіх. Провідним патогенетичним механізмом головного болю, на думку деяких авторів, $є$ подразнення екстра- і інтракраніальних артерій, твердої оболонки, V, IX, X черепних нервів і трьох верхніх шийних корінців; близько 90 \% всіх випадків болю в голові має у своїй основі судинний генез [20]. Інші автори вважають, що провідним механізмом $€$ психоемоційні перенапруження через часті стреси, приховану депресію або тривожність, а також напругу при неправильному положенні тіла людини, і найчастішим видом головного болю є біль напруги (78 \% всіх випадків головного болю) [21]. При головному болю напруги застосовують декілька методик: дія на рефлекторні точки (в зону опромінення потрапляють нижній косий м'яз, потиличний нерв, міжхребцевий суглоб С1-С2 зі зв'язковим апаратом; грудинно-ключично-сосковий м'яз, підпотиличні короткі косі і прямі м'язи, хребетна артерія зі задньою потиличною мембраною, атланто-окципіталь- 
ний суглоб зі зв'язковим апаратом), на проекцію сонної артерії, а також акупунктура.

Факторами, що провокують напад пучкового головного болю під час «пучка», є найчастіше алкоголь, прийом нітрогліцерину або введення гістаміну. Але нерідко провокаційні фрактори виявити не вдається. Іншою важливою особливістю пучкового головного болю є його часта приуроченість до нічного сну: від 50 до 75 \% нападів виникають у фразі «швидкого сну». Базова методика лазерної терапії аналогічна методиці лікування головного болю напруги. Додатково щодня проводять вплив на проекцію печінки і підшлункової залози.

Головний біль переважно оболонкового походження й обумовлений дилатацією гілок зовнішньої сонної артерії. Зовнішніми атрибутами цієї вазодилатації $€$ напруженість і підвищена пульсація поверхневої скроневої артерії, гіперемія кон'юнктиви і набухання слизової оболонки носа на боці цесралгії. На користь вазодилатації як причини головного болю свідчить і майже незмінний ефрект купіровання вазоконстрикторними речовинами (ерготамін). Істотну роль в патогенезі мігрені відіграє порушення обміну серотоніну, що документовано надлишковим виділенням із сечею після нападу мігрені 5-гідро-оксиіндолоцтової кислоти - продукту метаболізму серотоніну. Приуроченість у деяких хворих нападів мігрені до менструального періоду вказує на значення дисгормональних порушень і, мабуть, затримки рідини в організмі [20]. Застосовують поєднану методику лазеротерапії: на ділянку жовчного міхура і сліпої кишки, паравертебрально на ділянку C1-Th1, далі виконується акупунктура.

При корінцевих синдромах вплив спрямований на вертебральне вогнище у відповідному відділі хребта і паравертебральні зони, а також на дисциркуляторні явища в здавленому корінці.

При м'язово-компресійних (тунельних) синдромах рекомендують поєднувати методику внутрішньовенного лазерного опромінення крові з зовнішнім впливом імпульсного інфррачервоного НІЛО (паравертебрально на уражений хребетно-руховий сегмент, на уражений передній сходовий і малий грудний м'язи) [22].

При дитячому церебральному паралічі, незалежно від форми захворювання, рекомендують під час лазеротерапії впливати на такі п'ять зон [23]. 1. Так зване кістковомозкове море - зона, що проекційно відповідає підкорково-стовбуровим структурам і корі великого мозку. Вплив на кістковомозкове море в традиційному уявленні є найбільш ефективним при нервово-психічних захворюваннях. 3 урахуванням патогенезу ДЦП (постнатальна патологічна гетерохронія) вплив на цю зону цілком виправданий. Стимуляція тих структур, взаємодія між якими, зважаючи на патологічний процес, утруднена, надає антигетерохронічний ефект. 2. Задній і передній серединні меридіани і точки меридіана сечового міхура, розташовані на тулубі. Використання даних зон пояснюється тим, що статична м'язова тканина тулуба (фрілогенетично більш давня) іннервується не лише корковими відділами (довільні рухи), але і стріопалідарною системою. Отже, вплив на зазначені зони - це своєрідне тренування (стимуляція) статики, що надзвичайно важливо при ДЦП. 3. Аурикулярні зони, що дозволяють цілеспрямовано через систему черепних нервів (V, VII, IX, X пари) стимулювати підкорково-стовбурові структури. 4. Зони скальпа, на які за принципом зовнішньовнутрішніх взаємин можна надавати цілеспрямований вплив на визначені функції коркової речовини великого мозку. 5. Дистальні меридіальні точки, що використовуються для загальноенергетичного впливу і стимуляції або розслаблення конкретних м'язових груп або окремих м'язів. Залежно від форми ДЦП застосовують різні схеми лікування.

При дисциркуляторній енцефалопатії показано високу ефективність застосування надартеріальної матричної лазеротерапії на проекцію магістральних артерій голови [24]. Локалізація впливу залежить від клініко-гемодинамічних особливостей розвитку та перебігу захворювання. Лазеротерапію на проекцію обох загальних сонних артерій проводили при переважанні синдрому каротидної недостатності у хворих (передня локалізація). При синдромі вертебрально-базилярної недостатності впливали на обидві задньобокові поверхні шиї (задня локалізація). Також використовували ВлОК.

При ішемічних та травматичних мієлопатіях, враховуючи можливий рефрлекторний спазм судин, який виникає у відповідь на подразнення сегментарных симпатичних структур, слід впливати паравертебрально на спинальні ганглії, які розташовуються у міжхребцевому отворі. Таке лікування краще поєднувати з ВЛОК. Слід так само впливати на хребетну артерію, підключичну артерію, аорту (грудна і черевна частина), клубову артерію, де відходять сегментарні артерії, міжреберні артерії, на міжхребцевий отвір і на сегменти спинного мозку, особливо ті, які погано забезпечуються кров'ю (сегмент CIII-CIV, ThIV-ThV і ThIX-LI). В останню чергу слід впливати на уражені кінцівки (судинно-нервовий пучок і м'язи). НІЛО нормалізує перекисне окислення ліпідів, має протизапальну дію, сприяє розм'якшенню гліального рубця. Лазерна терапія при спінальній травмі сприяє не тільки поліпшенню мікроциркуляції в зоні ушкодження спинного мозку (знімає вагоспазм), але і застосовується для лікування або профрілактики пролежнів, а також інсекційних ускладнень з боку сечовивідних шляхів і дихальної системи. Показано, що ВЛоК сприяє якнайшвидшій нормалізації імунологічних показників хворих зі 
спінальною травмою, що сприяє профрілактиці розвитку гнійних легеневих ускладнень [25]. Поєднання ВЛОК 3 місцевим опроміненням контузійних вогнищ спинного мозку інфрачервоним НІЛО дозволяє швидше відновити втрачену функцію спинного мозку з вираженим регресом неврологічної симптоматики, уникнути розвитку пролежнів і в три рази швидше, порівняно з контролем, відновити мимовільне сечовипускання.

Лазерна терапія може бути застосована в якості базисного методу лікування міофасціальних больових синдромів, а також як додатковий метод у комплексному лікуванні хронічних вертеброгенних люмбоішіалгій.

При нейропатіях та невралгії трійничного нерва дані літератури свідчать про те, що в результаті лазеротерапії відбувається прискорення регресу симптоматики. Відновлення рухових фрункцій спостерігається у більшості хворих вже на другому тижні захворювання, у третини пацієнтів - на п'ятому-шостому сеансі. НІЛО сприятливо впливає на регіонарний кровотік в ділянці ураження. До 5-7-ї процедури позитивні гемодинамічні зрушення набувають стійкого характеру, а до моменту закінчення лікування у більшості хворих спостерігається достовірне підвищення амплітуди пульсового кровонаповнення на ураженій стороні обличчя, зниження судинного тонусу, зменшення коефріцієнта асиметрії. Найбільш виражені позитивні гемодинамічні зрушення спостерігаються у хворих в гострій стадії захворювання при ранньому початку курсу лт. Одночасно виявляють клінічні та електроміографічні ознаки поліпшення функцій мімічних м'язів [9]. Лазерна терапія проводиться у гострому, відновному і резидуальному (залишкові явища) періодах, при постневритичній контрактурі мімічних м'язів I-ІІ ступеня.

При неврастенії використовують контактну методику. Впливають послідовно: паравертебрально на комірцеву зону, на проекцію підключичної вени, на проекцію вилочкової залози, печінки, підшлункової залози, сліпої і сигмоподібної кишки.

Полінейропатія (поліневрит) - одночасне симетричне ураження кількох периферичних нервів, що проявляється млявими паралічами і чутливими порушеннями переважно в дистальних відділах кінцівок з ураженням в деяких випадках і черепних нервів. Полінейропатії включають судинні, алергічні, токсичні, метаболічні ураження периферичної нервової системи, а також пошкодження, зумовлені впливом різних фрізичних факторів - механічних, температурних, радіаційних. Розвиток хворобливих симптомів зазвичай підгострий або хронічний (виняток становить гостра демієлінізуюча полірадикулонейропатія Гійєна-Барре). Для цього захворювання характерні прогресуюча м'язова слабкість, атрофрія, парестезія, біль, гіперестезія або анестезія, зниження або випадіння рефлексів. На сьогодні відо- мо близько 150 етіологічних форм полінейропатій. При вегетативно-сенсорній пострадіаційній полінейропатії застосовують лазерну акупунктуру [9]. При діабетичній полінейропатії застосовують ВЛОК, комплексну магнітолазерну терапію, лазерну рефлексотерапію на тлі медикаментозного лікування.

Дослідження, що оцінюють ефективність застосування низькоінтенсивного лазерного опромінення для регенерації шванівських клітин і нейронів при ушкодженні периферичних нервів тварин, дали позитивні результати. За даними літератури, опромінення НІЛО викликає проліферацію шванівських клітин і посилення метаболізму нейронів з активним ростом нервових волокон [26-28]. Вивчення результатів впливу НІЛО 3 довжинами хвиль 632,8 і 780 нм на пошкоджені периферичні нерви лабораторних щурів показало: безпосередню захисну дію з посиленням фрункціональної активності пошкодженого нерва; тривале підтримання функціональної активності пошкодженого нерва; вплив НІЛО на процес утворення рубців у пошкодженому нерві; запобігання або зменшення процесу дегенерації відповідних нейронів спинного мозку; вплив на зростання аксонів і мієлінізацію. Крім того, пряме опромінення лазером спинного мозку покращує відновлення відповідного пошкодженого нерва. Експериментальна робота по імплантації органічного каналу в місце пошкодження перифреричного нерва та застосування культури нервових клітин у вогнищі ушкодження спинного мозку 3 наступним опроміненням низькоенергетичним лазером показала його високу ефективність для процесів регенерації. Значення результатів цих досліджень полягає в новому підході до застосування НІЛО і біологічних тканин при лікуванні тяжких ушкоджень периферичних нервів і спинного мозку. Проте для широкого клінічного застосування методики поки що не розроблено - відсутні об'єктивні критерії вибору методу і, найголовніше, не проведена оптимізація параметрів впливу.

Черепно-мозкова травма (ЧМТ) $є$ найбільш поширеною $з$ усіх видів механічних пошкоджень. В даний час загальноприйнятої класифрікації наслідків ЧМТ немає, але найчастіше виділяють періоди, пов'язані 3 різними видами ускладнень: гострий (від 2 до 10 тижнів), проміжний (від 2 до 6 міс.) і віддалений (до 2 років при клінічному видужанні і необмежено за часом при прогредієнтному перебігу захворювання). За даними численних досліджень, лазерну терапію можна проводити в усі періоди захворювання. Єдиним обмеженням для ВЛОК є наявність масивного субарахноїдального крововиливу. Слід підкреслити, що ВЛОК дозволяється застосовувати в комплексній інтенсивній терапії гострого періоду тяжкої черепно-мозкової травми. ВлОК проводиться з другої або третьої доби післяопераційного 
періоду при дотриманні ретельного інтраопераційного гемостазу. Крім лікування наслідків ЧМТ у гострий період, лазерна терапія може застосовуватися також і для вторинної профрілактики ускладнень черепно-мозкової травми (ішемія мозку, пневмонія, пролежні тощо). Для зменшення внутрішньочерепної гіпертензії або утруднення венозного відтоку з порожнини черепа, а також при гіперпродукції ліквору рекомендується стимулювати верхній шийний симпатичний вузол.

ВЛОК сприяє більш гладкому перебігу посттравматичного та післяопераційного періодів. У клінічному плані ефективність ВЛОК у комплексному лікуванні нейрохірургічних хворих (черепно-мозкова травма, пухлини, судинні захворювання) проявляється, насамперед, регресом загальномозкової симптоматики: зменшення ступеня порушення свідомості, прояву психомоторних розладів та інтенсивності головного болю. У багатьох нейрохірургічних хворих у післяопераційному періоді спостерігається дихальна недостатність, яка не компенсується гіпервентиляцією легень, що призводить до зниження споживання кисню тканинами, розвивається гіпоксія. Після ВЛОК істотно знижується артеріо-венозна різниця парціального тиску кисню і значно збільшується вено-артеріальна різниця по вуглекислоті, що призводить до збільшення дихального коефіцієнта більш ніж в 3 рази. Це свідчить про відновлення нормальної ефективності окислювально-відновних процесів, сприятливе для організму перемикання катаболічних процесів на анаболічні. В результаті рівень білка підвищується при зниженні рівня глюкози, ліквідується ацидоз в артеріальній і істотно знижується у венозній крові, збільшуються до норми бусерні резерви. Нормалізується осмолярність крові, зменшується кількість недоокислених продуктів обміну речовин, знижується концентрація глюкози та сечовини. ВЛОК має також нормалізуючий вплив на вміст фрракцій вільної і зв'язаної води при збереженні загальної кількості води в крові [29].

Розсіяний склероз (РС) - хронічне, прогресуюче захворювання центральної нервової системи, що проявляється розсіяною неврологічною симптоматикою і має прогредієнтно-ремітуючий перебіг. РС - автоімунне захворювання, при якому уражається мієлін, а за останніми даними - і аксони, що призводить до атрофрії головного мозку і необоротному неврологічному десріциту. На сьогодні це захворювання вважається невиліковним. Лазерна терапія показана хворим з тривалістю захворювання не більше 7 років. За даними [30, 31], кращі результати лікування у хворих, які мають вегетативний фрон адренергічної спрямованості, а з боку імунної системи напругу, переважно на рівні В-рецепторів, підвищення класу імуноглобулінів і циркулюючих імунних комплексів. Застосовується ВЛОК. Параметри впливу варіюють виходячи зі стану пацієнта.

При синдромі хронічної втомлюваності використовують ВЛОК, а також лазерну акупунктуру.

ВЛОК при ішемічних ураженнях головного мозку надає позитивний вплив на центральну та регіональну гемодинаміку, а також седативну та спазмолітичну дію. У 86 \% випадків досягається позитивний результат лікування, зниження смертності в 1,5-2,0 рази порівняно 3 контролем, уже на 2-3-му сеансі ВЛОК відбувається значний регрес (на десятки відсотків) основних клінічних симптомів та синдромів (біль голови, запаморочення, шум у голові, тахікардія, тремор, артеріальна гіпертензія). ВЛОК найбільш ефективно у хворих з терміном виявленого захворювання до 1 року [32]. Застосування ВЛОК при цереброваскулярних захворюваннях (атеросклероз судин головного мозку, артеріальна гіпертензія, остеохондроз шийного відділу хребта із синдромом хребетних артерій, дисциркуляторна енцефалопатія, порушення мозкового кровообігу різного рівня) показало переважну ефективність в осіб молодого віку (до 45 років), в яких спостерігається більш виражене регресування неврологічної симптоматики. Відзначено переважання ваготропного ефекту, якнайшвидша нормалізація реографрічних показників, що вказує на поліпшення кровонаповнення, зниження тонусу і зменшення периферичного опору судин головного мозку, згладжуються відмінності в кровообігу симетричних відділів мозку [33].

Лазерна терапія при епілепсії, застосована в оптимальних для конкретного хворого режимах, що забезпечує підвищення енергетики нейроцитів і їх біопотенціала, коригує ритмічну активність. НІЛО має седативну, помірну снодійну, спазмолітичну і антиконвульсантну дію, оскільки безпосередньо впливає на головний мозок і вегетативні центри. Підтвердженням $є$ проведені репрезентативні динамічні дослідження доплерографрічних і ЕЕГ-показників при багатовогнищевому епілептичному комплексі з придушенням при лазерному впливі в кінцевому підсумку вогнищ збудження. В результаті цих досліджень показано, що при лікувальному низькоінтенсивному лазерному впливі на кров, епілептогенні зони і точки акупунктури відбуваються корекційні зміни активності нейрональних утворень й інших структур головного мозку [33].

В.В. Скупченко і Т.Т. Маховская (1993) першими обґрунтували застосування ВЛОК при лікуванні хворих з ішемічним інсультом в гострому періоді [31]. Зіставлення результатів лікування в основній і контрольній групах дозволило встановити, що лазерна терапія виявилася більш ефективною, ніж традиційний медикаментозний спосіб лікування. Були виявлені й деякі 
особливості лазеротерапії даного захворювання, наприклад, метод був еорективним тільки для пацієнтів з тривалістю захворювання до 1 року. Отримані дані свідчать про безперечну перспективність такого поєднаного впливу за різної цереброваскулярної патології, і в першу чергу, при лікуванні хворих церебральним інсультом [32].

Підсумовуючи все вищесказане, можна констатувати, що лазеротерапія успішно використовується при багатьох неврологічних станах, які також є провідними синдромами при інфрекційних ураженнях нервової системи.

В результаті використання імпульсних режимів роботи, а також лазерів ультрафіолетового діапазону встановлено, що низькоінтенсивне лазерне опромінення має значний дезінтоксикаційний ефект, бактеріостатичну та бактерицидну дію за рахунок активації перекисного окислення ліпідів, що призводить до розриву і деструкції оболонок інфрекційних агентів [34].

Все це говорить про те, що лазеротерапія $€$ актуальним та перспективним методом лікування нейроінфекцій.

\section{Література}

1. Осипова Л.С. Особенности течения постгерпетических осложнений и их лечение на современном этапе / Л.С. Осипова, М.Т. Матюха // Новости медицины и фрармации. - 2007. - № 15 (221). - C. 13-14.

2. Цинзерлинг В.А. Инфекционные поражения нервной системы: вопросы этиологии, патогенеза и диагностики: Руководство для врачей многопрофильных стационаров / В.А. Цинзерлинг, М.Л. Чухловина. - СПб: ЭЛБИ-СПб, 2005. - 448 с.

3. Москвин С.В. Основы лазерной терапии / С.В. Москвин, В.А. Буйлин. - М.-Тверь, ООО «Изд-во «Триада», 2006. - 256 с.

4. Москвин С.В. Лазерная хромо- и цветотерапия / С.В. Москвин, В.Г. Купеев. - М.-Тверь: ООО «Изд-во «Триада», 2007. $-95 \mathrm{c}$.

5. Макашова В.В. Сравнительная оценка эфффективности различных способов применения лазеротерапии у больных острым вирусным гепатитом В / В.В. Макашова // Терапевт. архив. - 2001. - № 11. - С. 26-30.

6. Современные аспекты лазерной терапии / Под ред. В.Д. Попова. - Черкассы: Вертикаль, 2011. - 608 с.

7. Москвин С.В. Эфффективность лазерной терапии / С.В. Москвин. - М.: НПЛЦ «Техника», 2003. - 256 с.

8. Клинико-экспериментальные аспекты лечебного действия лазерного излучения / [М.И. Корпан, С. Магомедов, Н.И. Самосюк и др.] // Лікарська справа. - 2006. - № 4. - С. 52.

9. Москвин С.В. Эфффективность лазерной терапии / С.В. Москвин. Серия «Эффрективная лазерная терапия». Т. 2. - М.-Тверь: ООО «Изд-во «Триада», 2014. - 896 с.

10. Москвин С.В. Современные источники излучения и аппаратура для низкоинтенсивной лазерной терапии / С.В. Москвин // Лазер и Здоровье: Матер. 1-го межд. конгр. - Лимассол-Москва: Фирма «Техника», 1997. - С. 102-107.

11. Терапия матричными импульсными лазерами красного спектра излучения / [С.В. Москвин, А.Н. Наседкин, А.В. Кочетков и др.]. - М.-Тверь: ООО «Издательство «Триада», 2007. - 112 с.
12. Узденский А.Б. Реализация в клетках резонансных механизмов биологического действия сверхнизкочастотных магнитных полей / А.Б. Узденский // Электромагнитные поля и здоровье человека: Мат. 2-й междунар. конф. - М., 1999. - С. 43.

13. Лазеропунктура в невропатологии / [Г.Я. Анищенко, 3.М. Полянская, И.Г. Даллакян и др.]. - М., 1991. - 21 с.

14. Скупченко В.В. Фазотонный мозг / В.В. Скупченко. - Хабаровск: ДВО АН СССР, 1991. - 138 с.

15. Экспериментальные исследования фризико-химического действия токов при трансцеребральном применении / [В.М. Боголюбов, С.М. Зубкова, С.А. Радзиевский и др.] // Вопр. курорт., фризиотер. и ЛФК. - 1994. - Вып. 4. - С. 3-6.

16. Власова И.Г. Влияние низкоинтенсивного лазерного излучения на нервные клетки в условиях нарастающей гипоксии / И.Г. Власова // Лазерная медицина. - 2000. - Т. 4, № 3. - С. 24-29.

17. Рагинов И.С. Взаимодействие чувствительных нейронов и клеток-сателлитов при стимуляции регенерации нерва / И.С. Рагинов, Ю.А. Челышев, Т.Ф. Шагидуллин // Морфология. - 2002. - Т. 122, № 4. - С. 37-39.

18. Гейниц А.В. Внутривенное лазерное облучение крови / А.В. Гейниц, С.В. Москвин, А.А. Ачилов. - М., 2012. - 336 с.

19. Картелишев А.В. Комбинированная низкоинтенсивная лазерная терапия в психиатрической практике / А.В. Картелишев, Н.С. Вернекина. - М.: ТОО «Фирма «Техника», 2000. - 122 с.

20. Ходос Х.-Б.Г. Нервные болезни / Х.-Б.Г. Ходос. - М.: Медицинское информационное агентство, 2001. - 512 с.

21. Вейн А.М. Панические атаки / А.М. Вейн // Международ. мед. журн. - 1997. - Т. 3, № 3. - С. 75-79.

22. Дочиа А.А. Этапная комбинированная лазерная терапия в комплексной системе реабилитации больных с туннельными (мышечно-компрессионными) синдромами / А.А. Дочиа, А.P. Евстигнеев, Н.С. Вернекина. - Москва-Калуга: Изд. «Ротор-ПРЕСС», 2005. - $71 \mathrm{c}$

23. Самосюк И.3. Лазеротерапия и лазеропунктура в клинической курортной практике / И.З. Самосюк, В.П. Лисенюк, М.В. Лобода. - К.: Здоров'я, 1997. - 240 с.

24. Кочетков А.В. Надартериальная матричная лазерная терапия больных дисциркуляторной энцефалопатией / А.В. Кочетков, С.В. Москвин, А.Г. Космынин // Лазерная медицина. - 2005. - Т. 9, вып. 1. - С. 9-12.

25. Ступак В.В. Низкоинтенсивное лазерное излучение в лечении больных с позвоночно-спиновой травмой / В.В. Ступак // Травма нервной системы: Матер. ежегодн. науч.-практ. конф. I Под ред. А.Ю. Савченко. - Омск, 1999. - С. 74-75.

26. A single Transcutaneous Light Irradiation to Injured Peripheral Nerve: Comparative Study with Five Different Wavelengths / S. Rochkind et al. // Lasers in Medicine Science. - 1989. - Vol. 4. - P. 259.

27. Rochkind S. Systemic effects of low-power laser irradiation on the peripheral and central nervous system coetaneous wound, and burns / S. Rochkind, M. Rousso, M. Nissan // Laser Surg. Med. - 1989. - P. 9. 12,2, 174-182.

28. Transplantation of embryonal spinal cord nerve cells cultured on biodegradable microcarriers followed by low power laser irradiation for the treatment of traumatic paraplegia in rats / S. Rochkind, A. Shahar, M. Amon, Z. Nevo // Neurol. Res. - 2002. - Vol. 24, N 4. - P. 355360.

29. Модулирующий эфффект внутрисосудистого лазерного облучения крови на показатели гомеостаза у нейрохирургических больных / [П.В. Спасиченко, Г.М. Олейник и др.] // Низкоинтенсивное лазерное излучение в медицинской практике: Тез. докл. 4-й Дальневосточн. науч.-практ. конф. - Хабаровск, 1990. - С. 203-205. 
30. Скупченко В.В. Внутрисосудистое лазерное облучение крови при различных заболеваниях нервной системы / В.В. Скупченко, Т.Т. Маховская, Г.Л. Хандурина // Низкоинтенсивное лазерное излучение в медицинской практике: Тез. докл. 4-й Дальневосточн. науч.-практ. конф. - Хабаровск, 1990. - С. 143-150.

31. Скупченко В.В. Лазерная терапия в неврологии / В.В. Скупченко, Т.Т. Маховская. - Самара-Хабаровск, 1993. - С. 80.

32. Кочетков А.В. Лазерная терапия в неврологии / А.В. Кочетков $_{2}$ С.В. Москвин, А.Н. Карнеев. - М., 2012. - 360 с.

33. Скупченко В.В. Лазеротерапия в коррекции репаративного морфогенеза / В.В. Скупченко, Е.С. Милюдин // Лазерная медицина. - 2009.- № 1.- С. 13-16.

34. Вплив низькоінтенсивного лазерного випромінювання на біологічні об'єкти та чутливість мікроорганізмів до антибактеріальних препаратів / В.В. Пантьо, В.І. Ніколайчук, В.І. Пантьо, А.В. Корунець // Фотобіологія і фротомедицина. - 2010. - № 1, 2. - С. 80-87.

\section{MODERN POSSIBILITIES OF LASER NEUROINFECTIONS}

\author{
L.V. Berezina
}

SUMMARY. The literature review is devoted to modern concepts of laser irradiation on the organism. Shows the current possibilities for the use of laser therapy in the neuroinfections.

Key words: infection, laser irradiation, neuroscience, laser therapy.

Отримано 26.05.2016 р.

\title{
КЛІНІКО-МОРФОЛОГІЧНІ ТА ФУНКЦІОНАЛЬНІ ЗМІНИ НИРОК У ВІЛ-ІНФІКОВАНИХ
}

\author{
ВДНЗУ «Буковинський державний медичний університет»
}

Встановлено, що вірус імунодефіциту людини (ВІЛ) вражає ниркову систему. Наведені дані, що високоактивна антиретровірусна терапія (ВАAPT) має негативний вплив на функціональний стан нирок. Також виявляються морфологічні та фрункціональні зміни у ВІЛ-інфрікованих. У літературних джерелах описані поодинокі дані про медикаментозну корекцію цих змін.

Ключові слова: ВІЛ-інфрекція, ВІЛ-асоційована нефрропатія, фокально-сегментарний гломерулосклероз, хронічна ниркова недостатність.

Останні дані ВООЗ свідчать про те, що розповсюдження ВІЛ-інфрекції серед населення земної кулі відбувається швидше, ніж передбачалося раніше, і на сьогодні воно вже набуває ознак широкомасштабної ендемії. Згідно з прогнозом, до 2020 р. від ВІЛ-інфекції на планеті може померти 16 млн людей. Кількість ВІЛінфікованих у Східній Європі та Центральній Азії сьогодні досягла 1,6 млн осіб, що у 10 разів перевищує показник попереднього десятиріччя, 75 \% інорікованих - люди віком до 30 років [1]. Як визначають епідеміологічні спо- стереження, особливості поширення ВІЛ значною мірою пов'язані з шляхами інфрікування. Так, найбільш стрімке і агресивне зростання темпів розвитку епідемічного процесу ВІЛ-інорекції спостерігається серед ін'єкційних наркоспоживачів. Статевий шлях інфрікування (як гетеросексуальні, так і гомосексуальні стосунки) визначає повільне, але більш масове охоплення населення. Тому особливості епідемічного процесу головно визначаються саме активністю того чи іншого механізму передачі збудника інорекції на конкретному етапі розвитку епідемії.

Україна займає одне з перших місць в Європі за темпами поширення ВІЛ-інфрекції. На 1 липня 2015 р. зареєстровано 271942 ВІЛ-інфрікованих. Під медичним наглядом перебуває 124279 ВІЛ-позитивних. Показник поширеності складав 291,3 на 100 тис. населення та був на 7,2 \% менший, ніж за відповідний період 2014 р. Серед шляхів передачі переважає статевий шлях і складає 59,2 \% проти 57,8 \% за 2014 р. Протягом січня-червня 2015 р. зареєстровано 3992 нових випадки, а за відповідний період 2014 р. - 5306. Відмічається зменшення числа нових випадків ВІЛ-інфекції на 24,7 \%. 